\title{
STRUCTURA DIMENSIONALĂ A REPRODUCĂTORILOR SPECIEI RANA RIDIBUNDA DIN ECOSISTEMELE CODRILOR CENTRALI
}

https://doi.org/10.53937/9789975315975.07

\section{Cozari Tudor ${ }^{1,2}$, Gherasim Elena ${ }^{1}$}

1/nstitutul de Zoologie al Ministerului Educației, Culturii și Cercetării, Chișinău, R. Moldova;

2Universitatea de Stat din Tiraspol, Chișinău, R. Moldova cozaritudor@gmail.com,gherasimlenuta@gmail.com

În succesul reproductiv al amfibienilor un rol importanr îl are structura dimensională a reproducătorilor. Astfel, lungimea indivizilor maturi ai speciei Rana ridibunda variază în limitele 51,0-102,2 mm (M=80,4 44,7, $\mathrm{N}=30)$, a masculilor - $51,0-86,5 \mathrm{~mm}(\mathrm{M}=76,8 \pm 3,0 \mathrm{~N}=15)$, iar a femelelor - 56,5 - 102,2 mm (M=83,5 $\pm 5,4, N=15)$. Dimensiunile masculilor ce participă pentru prima oară la reproducere (cu vârsta de 2 ani) sunt de 51,0-56,6 mm ( $M=53,4 \pm 2,1)$, pe când dimensiunile femelelor la maturitate (care se produce la al 2 - 3-lea an) sunt mai mari decât cele ale

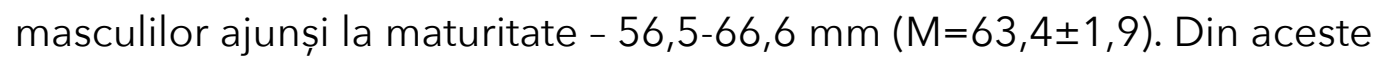
date rezultă că masculii și femelele acestei specii, cu excepția faptului că beneficiază de condiții asemănătoare de viață, inclusiv de nutriție, se deosebesc după ritmul de creștere, care, la femele, în perioada imatură este mai înalt decât cel al masculilor. Femelele, totodată, se maturizează cu un an mai târziu decât masculii și, prin urmare, au o perioadă de creștere mai îndelungată.

Analizând structura reproducătorilor în funcție de sex, s-a stabilit că o bună parte din masculi (până la 53,3\%) fac parte din categoriile dimensionale de 51,0-73,9 (cu vârsta de 2 - 4 ani), pe când cota majoritară a femelelor $(80,0 \%)$ o constituie grupele dimensionale cele mai mari ale populaţiei - 74,0-102,2 mm (cu vârsta de 4-9 ani). Printre masculi, cea mai numeroasă categorie dimensională a fost cea de 51,0-66,6 mm (cu vârsta de 3 ani), alcătuită din 40,0\% de masculi, pe când cele mai repre- 
zentative grupe dimensionale a femelelor au fost cele de 51,0 - 60,6 și 90,0 - 100,2 (cu vârsta de 4ani și respectiv de 9 ani) - 60,0\%.

Totodată s-a determinat și că structura dimensională a masculilor și femelelor, având o configurație dimensională asemănătoare, se deosebește, totuși, după cotele procentuale ale categoriilor dimensionale - femelele având categorii dimensionale mai mari. Aceasta ne demonstrează că vârsta, durata și ritmul de creștere a specimenelor este diferit - la femele perioada și ritmul de creștere fiind mai înalt. Fenomenul dat este caracteristic și altor ecaudate și se explică prin faptul că femelele, pentru a avea o prolificitate mai înaltă, au nevoie de dimensiuni corporale mai mari.

Analiza rezultatelor obținute, axate pe structura dimensională a reproducătorilor speciei R.ridibunda demonstrează că particularitățile sus menționate se încadrează în categoria fluctuațiilor numerice pentru populațiile de amfibieni cu un efectiv constant și viabil, care, în ecologia populațională sunt nominalizate drept populații cu strategie $\mathrm{K}$ de reproducere.

Studiul a fost efectuat în cadrul proiectelor fundamentale 15.187.0211F și 15.817.02.12F. 